Pak. j. sci. ind. res. Ser. A: phys. sci. 201558 (3) 136-141

\title{
Effect of Reconstitution Solvents and Containers on Kinetics and Safety of Cephradine Neutralised with L-Arginine
}

\author{
Aman ullah Khan ${ }^{a}$, Javeid Iqbala, Saif-ur-Rehman Khattak ${ }^{\mathrm{b} *}$, Najam-us-Saquib ${ }^{\mathrm{b}}$ and \\ Muhammad Saleem Qazic
}

${ }^{a}$ Faculty of Pharmacy, Hamdard University, Muhammad Bin Qasim Avenue, Karachi-74600, Pakistan

${ }^{b}$ Central Drugs Laboratory, DRAP, Block-B, S.M.C.H.S Karachi, Pakistan

'Pharmaceutical Research Centre, PCSIR Laboratories Complex, Karachi-75280, Pakistan

(received March 5, 2014; revised August 14, 2014; accepted August 15, 2014)

\begin{abstract}
The effect of reconstitution solvents such as water, $0.5 \%$ metronidazole solution, $0.9 \%$ sodium chloride and 5\% dextrose injections, have been investigated on the kinetics of degradation of cephradine neutralised with L-arginine contained in glass, polyvinylchloride (PVC) and polyethylene pthalate (PET) containers at 5,15 and $30^{\circ} \mathrm{C}$. The analytical method described in USP-31 for the analysis of cephradine injection was employed in this study and validation in respect of specificity, linearity, accuracy and precision was observed. The degradation of the compound showed first-order kinetics and the degradation rate constants ' $\mathrm{k}_{\mathrm{obs}}$ ' were found in the range of $1.84-3.07 \times 10^{-3} / \mathrm{h}\left(\mathrm{r}^{2}=0.990-0.999\right)$ at $5^{\circ} \mathrm{C}, 2.3-4.2 \times 10^{-3} / \mathrm{h}$ $\left(\mathrm{r}^{2}=0.993-0.999\right)$ at $15^{\circ} \mathrm{C}$ and $7.18-9.97 \times 10^{-3} / \mathrm{h}\left(\mathrm{r}^{2}=0.998-0.999\right)$ at $30^{\circ} \mathrm{C}$, respectively. Cephradine showed maximum stability in dextrose solution followed by water, sodium chloride and metronidazole injections, however, linear effect of containers on degradation rate could not be established. The extended degradation did not change the kinetics of the reaction. The abnormal toxicity/ safety test on mice for the admixtures in different containers at various temperatures showed no abnormal toxicity.
\end{abstract}

Keywords. cephradine, degradation kinetics, polyvinyl chloride, polyethylene phthalate, abnormal toxicity

\section{Introduction}

Cephradine is chemically (7R)-7-( $\alpha$-D-cyclohexa-1, 4dienylglucylamino)-3-methyl-3-cephem-4-carboxylic acid (USP, 2008). It is a first generation cephalosporin antibiotic and is available in different dosage forms such as capsules, dry suspension and dry powder injections (BP, 2009). Injection of cephradine must be neutralised by alkaline substances such as sodium carbonate or arginine to provide sufficient solubility and physiological acceptability. The drug is usually prescribed in the treatment of infections caused by sensitive organisms such as upper respiratory tract infections e.g. pharyngitis, sinusitis, otitis media, tonsillitis, larygotracheo-bronchitis; lower respiratory tract infections e.g. acute and chronic bronchitis and bronchopneumonia; urinary tract infections e.g. cystitis, urethritis, pyelonephritis; skin and soft tissue infections e.g. abscess, cellulitis, furunculosis; gastrointestinal tract infections e.g. bacillary dysentery, enteritis, peritonitis as well as bone and joint infections (Wisebritish, 1987).

In clinical practice cephradine injection is usually admixed with intravenous (IV) injection solutions such as dextrose,

*Author for correspondence; E-mail: drsaifdra@yahoo.com

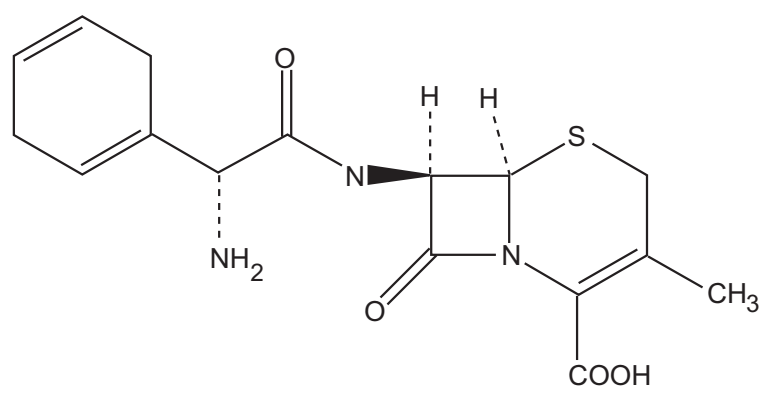

Fig. 1. Chemical structure of Cephradine.

normal saline and metronidazole injection solutions contained in various containers. These IV solutions can affect the stability of cehpradine as shown in the studies reported earlier (Wang and Monkhouse, 1983). The stability of these admixtures can be affected by a number of factors such as storage temperature, reconstitution solvent and the nature of the container (Conine et al., 1978; Florey, 1976; Yamana and Tsnji, 1976). The storage temperature not only influence the rate of degradation of the compound in the solvent but also affects the extraction of chemical compounds form containers to the injection solution migration of chemical from containers to the solvent kept 
inside it, and thereby rendering the solutions impure and unsafe (G I, 1999; Autian, 1963). The nature of the leachable is determined by the nature of the container (Danielson, et al., 1983; Ching et al., 1981; Corley et al., 1977; Jaeger and Rubin, 1972).

Thorough review of the literature revealed that very little work has been reported for these aspects of cephradine injection. This fact motivated the present study in which focus has been made on the effect of various reconstitution solvents used commonly in clinical practice i.e., water for injection, $0.5 \%$ metronidazole injection solution, $0.9 \%$ sodium chloride and 5\% dextrose solutions, on the kinetics of degradation of cephradine. Attempts have also been made to correlate the increase in temperature and the type of the container in which reconstitution is made with the rate of degradation of the compound. The effect of extended degradation on the kinetics of the reaction has also been evaluated. Experiments have also been performed to assess the abnormal toxicity of cephradine injection when admixed with these IV solutions in containers made of different materials such as polyvincychloride (PVC), glass and polyethylene phthalate (PET) at 5,15 and $30{ }^{\circ} \mathrm{C}$.

\section{Materials and Methods}

Materials. Cephradine (neutralised with L-arginine) samples and reference standard were donated by M/S. GSK Pakistan (Pvt.) Ltd., Karachi. Samples of metronidazole (flagyl injection, Sanofi Aventis, Pakistan), sodium chloride injection and dextrose injection (Plasaline and plades-5 injections, Outsuka, Pakistan) and water for injection (Tabros Pharma, Pakistan) were purchased from authentic distributors. All the reagents and solvents, used in this study were of analytical and spectroscopic grades, respectively. Freshly prepared double distilled water was used throughout this work.

HPLC apparatus and conditions. A high performance liquid chromatographic system (Class 20A, Kyoto, Japan) provided with a LC-20 AT pump with gradient mixer, an SPD-20A UV visible detector, a stainless steel column (C$18,5 \mu 4.6 \times 150 \mathrm{~mm}$ id, Hypersil, Thermo Quest, USA) and an inbuilt CBM-20A lite communication bus module was used in this study. The data collection and integration were obtained by using SHIMADZU LC solution computer software version 1.2 (Kyoto, Japan). All separations were achieved isocratically at room temperature $\left(20 \pm 1^{\circ} \mathrm{C}\right)$. The mobile phase was degassed and filtered mixture of methanol: $0.5 \mathrm{M}$ sodium acetate: $0.7 \mathrm{~N}$ glacial acetic acid: water (200:15:3: 782, v/v). The flow rate was maintained at $1.75 \mathrm{~mL} / \mathrm{min}$ with detection at $254 \mathrm{~nm}$. Injection volume was $20 \mu \mathrm{L}$.
pH measurement. The $\mathrm{pH}$ measurements were performed with a $\mathrm{pH}$ meter (Wertheim, Germany). Electrode of the $\mathrm{pH}$ meter was standardised with buffer solutions ( $\mathrm{pH} 2.0$, 4.0 and 7.0, Merck) at $25^{\circ} \mathrm{C}$.

Degradation studies of cephradine in admixture with intravenous solutions. An accurately weighed quantity of $10 \mathrm{~g}$ of cephradine was taken in $1000 \mathrm{~mL}$ volumetric flask. A volume of about $500 \mathrm{~mL}$ of $0.9 \%$ sodium chloride solution or $5 \%$ dextrose solution or $0.5 \%$ metronidazole solution or water for injection was added to the flask. The flask was kept in ultrasonic bath to promote dissolution of the drug in the solvent. After complete dissolution of the drug powder in the solvent, the volume was made up to the mark with additional volume of the respective solvent. Zero time samples were withdrawn for analysis while nine aliquots, each of $50 \mathrm{~mL}$ of the remainder samples solution were withdrawn into three groups, each of PVC, glass and PET containers. One sample from each group was placed at $5^{\circ} \mathrm{C}$, the other at $15^{\circ} \mathrm{C}$ while, the third at $30{ }^{\circ} \mathrm{C}$ in refrigerator or oven for $24 \mathrm{~h}$. Samples were withdrawn at regular interval of $6 \mathrm{~h}$, diluted with the mobile phase (final concentration $100 \mu \mathrm{g} / \mathrm{mL}$ ) and analysed by HPLC. Quantification was made by comparing peak area or height of the sample to the peak area or height of the standard solution.

To determine the effect (if any) of extended degradation on the kinetics of degradation reaction of cephradine, the drug powder was dissolved in water for injection in glass container and kept at $50^{\circ} \mathrm{C}$ for $2 \mathrm{~h}$ to produce sufficient amount of the degradation products. The degraded solution was analysed by HPLC to estimate the extent of degradation. The degraded solution was kept further at $30^{\circ} \mathrm{C}$ in an oven and samples were withdrawn at regular time intervals. Any change in the kinetic behaviour of cephradine was determined by comparing the kinetic data at $30{ }^{\circ} \mathrm{C}$ of the pre-heated sample and the sample which was not initially heated at $50{ }^{\circ} \mathrm{C}$ for two hours.

Abnormal toxicity/safety test. Eight groups (each of 5 healthy mice between 17-23g of weight for each container at each temperature) were selected for this study. First 4 groups were injected intravenously with $0.5 \mathrm{~mL}$ of $10 \mathrm{mg} / 1 \mathrm{~mL}$ solution of cephradine in water for injection, $0.9 \%$ sodium chloride solution, $5 \%$ dextrose and $0.5 \%$ metronidazole injections, respectively. The time of the injection was kept $20-30 \mathrm{sec}$. To the rest of the four groups $0.5 \mathrm{~mL}$ of the same amount of diluents were administered over a similar period of 20-30 sec. The 
criteria for pass and fail was kept as: None of the mice must die within $24 \mathrm{~h}$. If one of the animals dies within $24 \mathrm{~h}$, the test will be repeated. None of the animals in the second group must die within the $24 \mathrm{~h}$.

Statistical analysis. The orders of the degradation reactions were determined graphically using the half-life methods. The observed degradation rate constants $\left(\mathrm{k}_{\mathrm{obs}}\right)$ were estimated from the slope of the log-linear phase of declining cephradine concentration versus time plots. All first-order plots reported in this study were linear with the square of correlation coefficient $\left(\mathrm{r}^{2}\right)$ greater than 0.990 . The half-lives were calculated using the half life equation $\left(t \frac{1}{2}=\log (2) / k\right.$.) Data was expressed as the mean of replicate determinations $(n=3)$. Statistical analyses were achieved using statistical package for social sciences (SPSS, version 15).

\section{Results and Discussion}

Validation of analytical method. The USP-31 method for analysis of cephradine injection (USP, 2008) was slightly modified (changing flow rate from $1 \mathrm{~mL}$ per minute to $1.75 \mathrm{~mL}$ per minute and the $\mathrm{C}-18$ column id from $4.6 \times 250 \mathrm{~mm}$ to $4.6 \times 150 \mathrm{~mm}$ ) and used in this study. The method was partially validated by including parameters like specificity, linearity, accuracy and precision. A linear response $\left(r^{2}=0.9995-0.9998\right)$ was shown by the compound in all solvents when measured by both peak area and height within the concentration range of $5-125 \mu \mathrm{g} / \mathrm{mL}$ (Table 1).

The reconstitution solvents and the degradation products did not interfere with the peak of the compound (Fig. 2). The method was also found accurate as overall mean of the recoveries of the method was found within $99-101 \%$ of the $50-150 \%$ range of the nominal content $(100 \mu \mathrm{g} / \mathrm{mL})$. The inter-day and intra-day precision of the method were also found within limits i.e. \% RSD below $2 \%$ (Table 2 ).

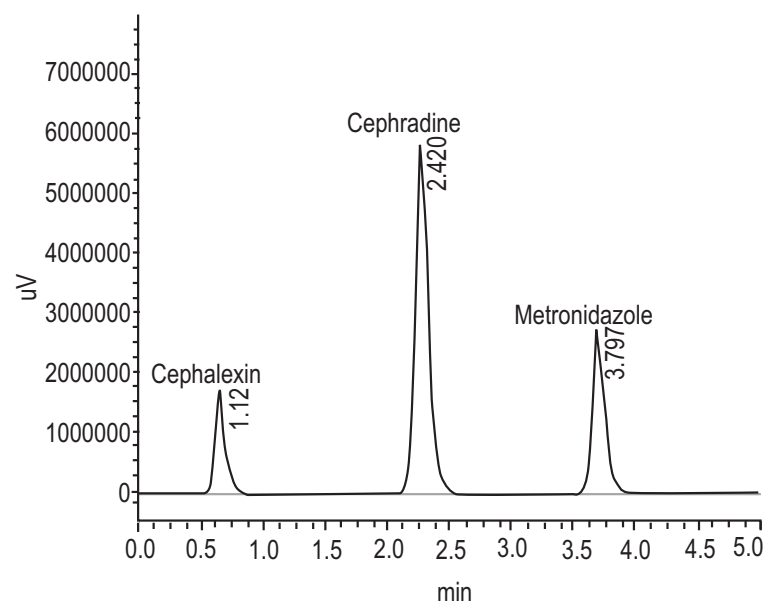

Fig. 2. HPLC chromatogram of cephradine solution spiked with the excipiant metronidazole and degradation product cephalexin.

Kinetics of degradation of cephradine in IV solutions. The kinetic treatment of the data on degradation of cephradine in the solvents studied showed that degradation of the drug follows first-order kinetics. This observation is in agreement with the previous studies (Yamana and Tsnji, 1976). The observed rate constants; $k_{o b s}$, for the degradation of the drug in the solvents stored in glass, polyethylene phthalate and polyvinylchloride containers at 5,15 and $30^{\circ} \mathrm{C}$, are in the range of $1.84-9.97 \times 10^{-3} / \mathrm{h}$ with square of a correlation ranging from 0.9905-0.9999 (Table 3-5). The half-lives of the reactions were found to be in the range of 2.40-15.69 days. The highest rate of degradation of the drug was found in $5 \%$ dextrose injection and water for injection followed by $0.9 \%$ sodium chloride injection and metronidazole solution, respectively. The rate of degradation was also found to accelerate with increase in temperature by 1.4 and 3.2 folds, respectively, at $15^{\circ} \mathrm{C}$ and $30^{\circ} \mathrm{C}$ as compared to $5^{\circ} \mathrm{C}$.

The increase in degradation rate of the drug with increase in temperature has also been evidenced by earlier

Table 1. Linearity and accuracy data of cephradine in IV solutions

\begin{tabular}{|c|c|c|c|c|}
\hline Vehicle & Slope & Y-Intercept & $\begin{array}{l}\text { Correlation } \\
\text { coefficient } \\
\left(\mathrm{r}^{2}\right)\end{array}$ & $\begin{array}{l}\% \text { Recovery } \\
\text { (Means of } \% \\
\text { amount found } \\
\text { from } 50 \%, 100 \% \\
\& 150 \% \text { amount of } \\
\text { cephradine added) }\end{array}$ \\
\hline Water for injection & 0.4365 & -0.0145 & 0.9996 & $99.93,99.78,99.80$ \\
\hline $5 \%$ dextrose & 0.8344 & -0.0313 & 0.9995 & $99.63,100.16,100.06$ \\
\hline $0.9 \% \mathrm{NaCl}$ solution & 0.28267 & -0.02324 & 0.9998 & $100.10,99.96,100.19$ \\
\hline $0.5 \%$ Metronidazole solution & 0.4480 & -0.0211 & 0.9997 & $99.93,99.85,99.95$ \\
\hline
\end{tabular}


Table 2. Intra-day and Inter-day repeatability results of cephradine in various IV solutions

\begin{tabular}{|c|c|c|c|c|c|c|c|c|}
\hline \multirow[t]{2}{*}{ Sample no. } & \multicolumn{2}{|c|}{$\begin{array}{l}\% \text { Cephradine in } \\
\text { water for injection }\end{array}$} & \multicolumn{2}{|c|}{$\begin{array}{l}\% \text { Cephradine in } \\
5 \% \text { dextrose } \\
\text { solution }\end{array}$} & \multicolumn{2}{|c|}{$\begin{array}{l}\% \text { Cephradine in } \\
0.9 \% \mathrm{NaCl} \\
\text { solution }\end{array}$} & \multicolumn{2}{|c|}{$\begin{array}{l}\text { \% Cephradine in } \\
5 \% \text { metronidazole } \\
\text { solution }\end{array}$} \\
\hline & Day-I & Day-II & Day-I & Day-II & Day-I & Day-II & Day-I & Day-II \\
\hline \multicolumn{9}{|l|}{$1^{\text {st }}$ analyst } \\
\hline 1 & 101.6 & 100.9 & 100.8 & 101.0 & 100.8 & 101.0 & 100.6 & 100.4 \\
\hline 2 & 100.3 & 99.7 & 100.8 & 101.0 & 100.7 & 100.9 & 100.5 & 100.5 \\
\hline 3 & 100.2 & 100.1 & 100.6 & 100.9 & 100.7 & 100.6 & 100.5 & 101.0 \\
\hline 4 & 100.6 & 101.0 & 100.3 & 100.2 & 100.3 & 100.6 & 99.7 & 101.0 \\
\hline 5 & 99.9 & 100.7 & 100.1 & 100.6 & 100.6 & 99.8 & 100.3 & 100.9 \\
\hline Mean & 100.52 & 100.48 & 100.52 & 100.74 & 100.62 & 100.46 & 100.32 & 100.76 \\
\hline$\%$ RSD & 0.65 & 0.56 & 0.31 & 0.34 & 0.19 & 0.49 & 0.36 & 0.28 \\
\hline \multicolumn{9}{|l|}{$2^{\text {nd }}$ analyst } \\
\hline 1 & 101.2 & 100.3 & 101.1 & 100.7 & 100.7 & 100.2 & 100.5 & 100.9 \\
\hline 2 & 101.4 & 100.2 & 101.0 & 100.5 & 101.0 & 100.2 & 100.5 & 100.2 \\
\hline 3 & 100.9 & 100.5 & 99.9 & 100.5 & 101.0 & 100.2 & 100.9 & 100.2 \\
\hline 4 & 100.8 & 101.2 & 100.8 & 100.8 & 99.8 & 100.8 & 100.7 & 99.8 \\
\hline 5 & 100.1 & 100.2 & 100.4 & 101.0 & 100.3 & 100.6 & 101.0 & 99.7 \\
\hline Mean & 100.88 & 100.48 & 100.64 & 100.7 & 100.56 & 100.4 & 100.72 & 100.16 \\
\hline$\%$ RSD & 0.44 & 0.53 & 0.49 & 0.21 & 0.51 & 0.28 & 0.23 & 0.22 \\
\hline
\end{tabular}

Table 3. Apparent first-order rate consents $\left(\mathrm{k}_{\mathrm{obs}}\right)$ of cephradine in various solvents in various containers at $5^{\circ} \mathrm{C}$.

\begin{tabular}{|c|c|c|c|c|c|c|c|c|c|}
\hline \multirow[t]{2}{*}{ Solvents } & \multicolumn{3}{|c|}{ Glass containers } & \multicolumn{3}{|c|}{ PET containers } & \multicolumn{3}{|c|}{ PVC containers } \\
\hline & $\begin{array}{l}\mathrm{k}_{\mathrm{obs}} \times \\
10^{3} / \mathrm{h}\end{array}$ & $r^{2}$ & $\begin{array}{l}\text { Half-life } \\
\left(\mathrm{t}_{1 / 2}\right) \\
\text { (day) }\end{array}$ & $\begin{array}{l}\mathrm{k}_{\mathrm{obs}} \times \\
10^{3} / \mathrm{h}\end{array}$ & $r^{2}$ & $\begin{array}{l}\text { Half-life } \\
\left(\mathrm{t}_{1 / 2)}\right) \\
(\text { day })\end{array}$ & $\begin{array}{l}\mathrm{k}_{\mathrm{obs}} \times \\
10^{3} / \mathrm{h}\end{array}$ & $r^{2}$ & $\begin{array}{l}\text { Half-life } \\
\left(\mathrm{t}_{1 / 2}\right) \\
\text { (day) }\end{array}$ \\
\hline $5 \%$ dextrose solution & 2.68 & 0.9994 & 10.77 & 2.68 & 0.9997 & 10.77 & 3.07 & 0.9972 & 9.4 \\
\hline Water for injection & 2.68 & 0.9994 & 10.77 & 2.0 & 0.9996 & 12.55 & 2.3 & 0.9991 & 12.55 \\
\hline $0.9 \% \mathrm{NaCl}$ solution & 1.92 & 0.6688 & 15.03 & 1.91 & 0.9905 & 15.11 & 1.91 & 0.9996 & 15.11 \\
\hline $0.5 \%$ Metronidazole solution & 1.84 & 0.9905 & 15.69 & 2.3 & 0.9999 & 12.55 & 1.91 & 0.9995 & 15.11 \\
\hline
\end{tabular}

Table 4. Apparent first-order rate consents $\left(\mathrm{k}_{\mathrm{obs}}\right)$ of cephradine in various solvents in various containers at $15^{\circ} \mathrm{C}$.

\begin{tabular}{|c|c|c|c|c|c|c|c|c|c|}
\hline \multirow[t]{2}{*}{ Solvents } & \multicolumn{3}{|c|}{ Glass containers } & \multicolumn{3}{|c|}{ PET containers } & \multicolumn{3}{|c|}{ PVC containers } \\
\hline & $\begin{array}{c}\mathrm{k}_{\text {obs }} \times \\
10^{3} / \mathrm{h}\end{array}$ & $r^{2}$ & $\begin{array}{l}\text { Half-life } \\
\left(\mathrm{t}_{1 / 2}\right) \\
\text { (day) }\end{array}$ & $\begin{array}{l}\mathrm{k}_{\mathrm{obs}} \times \\
10^{3} / \mathrm{h}\end{array}$ & $r^{2}$ & $\begin{array}{l}\text { Half-life } \\
\left(\mathrm{t}_{1 / 2)}\right) \\
\text { (day) }\end{array}$ & $\begin{array}{l}\mathrm{k}_{\mathrm{obs}} \times \\
10^{3} / \mathrm{h}\end{array}$ & $r^{2}$ & $\begin{array}{l}\text { Half-life } \\
\left(\mathrm{t}_{1 / 2}\right) \\
\text { (day) }\end{array}$ \\
\hline $5 \%$ dextrose solution & 3.83 & 0.9939 & 7.53 & 4.2 & 0.9996 & 6.87 & 4.2 & 0.9996 & 6.87 \\
\hline Water for injection & 3.45 & 0.9999 & 8.36 & 3.45 & 0.9998 & 8.36 & 3.45 & 0.9997 & 8.36 \\
\hline $0.9 \mathrm{NaCl}$ solution & 3.07 & 0.9999 & 9.40 & 2.3 & 0.9999 & 12.55 & 3.07 & 0.9999 & 9.40 \\
\hline $0.5 \%$ Metronidazole solution & 2.3 & 0.9997 & 12.55 & 2.68 & 0.9981 & 10.77 & 2.3 & 0.9994 & 12.55 \\
\hline
\end{tabular}


Table 5. Apparent first-order rate consents $\left(\mathrm{k}_{\mathrm{obs}}\right)$ cephradine in various solvents in various containers at $30{ }^{\circ} \mathrm{C}$.

\begin{tabular}{|c|c|c|c|c|c|c|c|c|c|}
\hline \multirow[t]{2}{*}{ Solvents } & \multicolumn{3}{|c|}{ Glass containers } & \multicolumn{3}{|c|}{ PET containers } & \multicolumn{3}{|c|}{ PVC containers } \\
\hline & $\begin{array}{c}\mathrm{k}_{\mathrm{obs}} \times \\
10^{3} / \mathrm{h}\end{array}$ & $r^{2}$ & $\begin{array}{l}\text { Half-life } \\
\left(\mathrm{t}_{1 / 2}\right) \\
\text { (day) }\end{array}$ & $\begin{array}{l}\mathrm{k}_{\text {obs }} \times \\
10^{3} / \mathrm{h}\end{array}$ & $r^{2}$ & $\begin{array}{l}\text { Half-life } \\
\left(\mathrm{t}_{1 / 2}\right) \\
\text { (day) }\end{array}$ & $\begin{array}{l}\mathrm{k}_{\mathrm{obs}} \times \\
10^{3} / \mathrm{h}\end{array}$ & $r^{2}$ & $\begin{array}{l}\text { Half-life } \\
\left(\mathrm{t}_{1 / 2}\right) \\
\text { (day) }\end{array}$ \\
\hline $5 \%$ dextrose solution & 9.21 & 0.9996 & 3.13 & 9.97 & 0.9997 & 2.89 & 11.8 & 0.9996 & 2.4 \\
\hline Water for injection & 9.21 & 0.9995 & 3.13 & 9.59 & 0.9993 & 3.01 & 9.21 & 0.9989 & 3.13 \\
\hline $0.9 \% \mathrm{NaCl}$ solution & 6.52 & 0.9995 & 4.42 & 6.14 & 0.9995 & 4.70 & 7.67 & 0.9995 & 3.76 \\
\hline $0.5 \%$ Metronidazole solution & 6.14 & 0.9996 & 4.70 & 6.52 & 0.9996 & 4.42 & 6.14 & 0.9993 & 4.70 \\
\hline
\end{tabular}

Table 6. Abnormal toxicity/safety test for cephradine injection admixed with various IV solutions in different containers at 5,15 and $30^{\circ} \mathrm{C}$.

\begin{tabular}{|c|c|c|}
\hline \multirow[t]{2}{*}{ Injection composition } & \multicolumn{2}{|c|}{ Observations } \\
\hline & $\begin{array}{l}\text { Immediate after } \\
\text { injection }\end{array}$ & $\begin{array}{l}24 \mathrm{~h} \text { after } \\
\text { injection }\end{array}$ \\
\hline Cephradine admixed with water for injection & $\begin{array}{l}\text { No signs of any } \\
\text { untoward reaction }\end{array}$ & $\begin{array}{l}\text { No signs of any } \\
\text { untoward reaction }\end{array}$ \\
\hline Cephradine admixed with $5 \%$ dextrose solution & $\begin{array}{l}\text { No signs of any } \\
\text { untoward reaction }\end{array}$ & $\begin{array}{l}\text { No signs of any } \\
\text { untoward reaction }\end{array}$ \\
\hline Cephradine admixed with $0.9 \mathrm{Nacl}$ solution & $\begin{array}{l}\text { No signs of any } \\
\text { untoward reaction }\end{array}$ & $\begin{array}{l}\text { No signs of any } \\
\text { untoward reaction }\end{array}$ \\
\hline Cephradine admixed with $0.5 \%$ metronidazole solution & $\begin{array}{l}\text { No signs of any } \\
\text { untoward reaction }\end{array}$ & $\begin{array}{l}\text { No signs of any } \\
\text { untoward reaction }\end{array}$ \\
\hline Water for injection & $\begin{array}{l}\text { No signs of any } \\
\text { untoward reaction }\end{array}$ & $\begin{array}{l}\text { No signs of any } \\
\text { untoward reaction }\end{array}$ \\
\hline $5 \%$ dextrose solution & $\begin{array}{l}\text { No signs of any } \\
\text { untoward reaction }\end{array}$ & $\begin{array}{l}\text { No signs of any } \\
\text { untoward reaction }\end{array}$ \\
\hline $0.9 \% \mathrm{NaCl}$ solution & $\begin{array}{l}\text { No signs of any } \\
\text { untoward reaction }\end{array}$ & $\begin{array}{l}\text { No signs of any } \\
\text { untoward reaction }\end{array}$ \\
\hline $0.5 \%$ Metronidazole solution & $\begin{array}{l}\text { No signs of any } \\
\text { untoward reaction }\end{array}$ & $\begin{array}{l}\text { No signs of any } \\
\text { untoward reaction }\end{array}$ \\
\hline
\end{tabular}

investigations (Conine et al., 1978). The reaction container also influenced the rate of degradation. In metronidazole injection, and in water for injection, the highest rate was noted in PET containers and the lowest in glass and PVC containers. In dextrose injection the highest degradation rate was seen in PVC while the lowest in glass containers. In sodium chloride solution the highest rate of degradation was noted in PVC containers while the lowest in PET containers. The variable degradation rate in different containers clearly indicates the role of containers on the degradation.

Change in $\mathbf{p H}$ and kinetics of the reaction. A slight increase in $\mathrm{pH}$ of the admixtures was also observed as seen with other cephalosporins (Viaene et al., 2002). Extended degradation lowers the concentration of the solute in the solution which has been shown in some earlier studies to change the kinetics of degradation reaction (Ito et al., 2005; Meakin et al., 1978), but in the present of case, the comparison of kinetics of the sample at $30{ }^{\circ} \mathrm{C}$ after being degraded at $50{ }^{\circ} \mathrm{C}$ for $2 \mathrm{~h}$ with the sample degraded at $30{ }^{\circ} \mathrm{C}$ (not treated initially) did not show any difference.

Abnormal toxicity. The identification and quantification of any leachable could not be made in this study, however, any toxicity associated with such phenomenon was evaluated by conducting abnormal toxicity tests of the admixtures stored in glass, PVC and PET containers at 5, 15 and $30^{\circ} \mathrm{C}$. Results of these experiments showed no evidence of any abnormal toxicity of the admixtures under the conditions studied (Table 6).

\section{Conclusion}

Thermal degradation of cephradine in admixture with 5\% dextrose injection, $0.9 \%$ sodium chloride injection or $0.5 \%$ metronidazole injection follows first-order kinetics. The 
kinetics of degradation of the compound are influenced by temperature, solvent and container used however, the abnormal toxicity test is not influenced. The results of these studies necessitate that appropriate storage conditions and containers must be ensured while storing solutions of the product. Delayed injectability of the product while admixed with intravenous solutions should also be avoided in clinical practice.

\section{Acknowledgement}

The authors are thankful to M/S. GSK Pakistan (Pvt) Ltd for providing samples and reference standards of cephradine. Thank are also due to Dr. Ashraf of Nabi Qasim Pharma for providing technical facilities for this work.

\section{References}

Autian, J. 1963. Plastics in pharmaceutical practice and related fields, Journal of Pharmaceutical Science, 52: 1-23, 105-122.

BP, 2009. British Pharmacopoeia, pp. 2382-2384, $15^{\text {th }}$ edition, The Stationary Office, London, UK.

Conine, J.W., Johnson, D.W., Coleman, D.L. 1978. Current Therapeutic Research, 24: 967.

Ching, N.P.H., Jham, G.N., Subbarayan, C., Grossi, C., Hicks, R., Nealon, Jr. TF. 1981. Gas chromatographic quantitation of two plasticizers contaminating intravenous fluids stored in plastic containers. Journal of Chromatogram, 225: 196-201.

Corley, J.H., Needham, T.E., Sumner, E.D., Mikeal, R. 1977. Effect of various factors on the amount of plasticizer in intravenous solutions packaged in flexible bags. American Journal of Hospital Pharmacy, 34: 259-264.

Danielson, J.W., Oxborrow, G.S., Placencia, A.M. 1983. Chemical leaching of rubber stoppers into parenteral solutions. Journal of Parenteral Science and Technology, 37: 89-92.

Florey, K. 1976. Analytical Profiles of Drug Substances. vol. V, pp. 46-47, Academic Press Inc., NY, USA.
GI, 1999. Container Closure Systems for Packaging Human Drugs and Biologics. In: Guidance for Industry, pp. 1-37, US Department of Health and Human Services, Food and Drugs Administration, Rockville MD, USA.

Ito, N., Suzuki, M., Kusai, A., Takayama, K. 2005. Effect of initial concentration on stability of panipenem in aqueous solution. Chemical Pharmceutical Bulletin, 53: 323-327.

Jaeger, R.J., Rubin, R.J. 1972. Migration of a phthalate ester plasticizer from polyvinyl chloride blood bags into stored human blood and its localization in human tissues, The New England Journal of Medicine, 287: 1114-8.

Meakin, B.J., Stevens, J., Davies, D.J. 1978. The effect of drug concentration on the thermal (dark) degradation of promethazin hydrochloride in aqueous solution, Journal of Pharmacy and Pharmacology, 30: $75-80$.

USP, 2008. United States Pharmacopoeia 31 - National Formulary 26United States Pharmacopeial Convention, pp. 1878-1879, Rockville, MD, USA.

Viaene, E., Chanteux, H., Servias, H., Mingeot-Lecercq, M.P., Tulkens, P.M. 2002. Comparative stability study of antipseudomonal $\beta$-lactams for potential administration through portable elastomeric pumps (home therapy for cystic fibrosis patients) and motor-operated syringes (intensive care units). Antimicrobial Agents and Chemotherapy, 46: 2327 2332.

Wang, Y.J., Monkhouse, D.C. 1983. Solution stability of cephradine neutralized with arginine orsodium bicarbonate. Journal of American Hospital Pharmacy, 40: 432-434.

Wisebritish, R. 1987. BMJ 2, 40 Doi: 10.1136/bmj. 2.6129.40.

Yamana, T., Tsnji, A. 1976. Comparitive stability of cephalosporins in aqueous solution: Kinetics and mechanisms of degradation. Journal of Pharmaceutical Sciences, 65: 1563-1574. 